\title{
KEPUASAN PELANGGAN DITINJAU DARI KUALITAS PRODUK, CITRA MEREK DAN PELAYANAN PADA OUTLET 3 SECOND SURAKARTA (Consumer Purchase Interest Assessed From The Atmosphere Store, Location, And Word Of Mouth Case Study On Solo Boutique)
}

\author{
Erna Mada Lena' ${ }^{1}$, Bambang Mursito², Sri Hartono ${ }^{3}$ \\ ${ }^{1}$ Fakultas Ekonomi Manajemen, E-mail ernamada41@gmail.com \\ ${ }^{2}$ Fakultas Ekonomi Manajemen, E-mail bambangmursito1959@gmail.com \\ ${ }^{3}$ Fakultas Ekonomi Manajemen, E-mail srihartono.uniba@gmail.com
}

Info Artikel

Diterima Februai 1, 2021

Direvisi Februari 20, 2021

Dipubikasi Maret 20, 2021

\section{Kata Kunci:}

kualitas produk, citra merek, pelayanan, kepuasan pelanggan

\section{Keywords :}

product quality, brand image, service, customer

\begin{abstract}
Abstrak
Persaingan bisnis fashion saat ini pelaku usaha dituntut mempunyai strategi yang mampu untuk menarik dan mempertahankan konsumen guna keberlangsungan perusahannya. Penelitian ini bertujuan guna untuk menguji kualitas produk, citra merek dan pelayanan secara simultan berpengaruh terhadap kepuasan pelanggan pada Outlet 3 Second Surakarta. Sampel penelitian sampel accidental sampling sebanyak 100 konsumen dengan metode regresi linier berganda. Hasil penelitian kualitas produk, citra merek dan pelayanan secara simultan dan parsial berpengaruh signifikan terhadap kepuasan pelanggan pada Outlet 3 Second Surakarta. Kontribusi dari ketiga variabel independen dapat menjelaskan kepuasan pelanggan sebesar 38,6\% dan sisanya dipengaruhi dari variabel lain

Abstract
Current fashion business competition is required to
\end{abstract}


have a strategy that is able to attract and retain consumers for the sustainability of their company. This study aims to test product quality, brand image and service simultaneously affect customer satisfaction at Outlet 3 Second Surakarta. The sample research sample is 100 consumers accidental sampling with multiple linear regression method. The results of product quality, brand image and service simultaneously and partially have a significant effect on customer satisfaction research at Outlet 3 Second Surakarta. The contribution of the three independent variables can explain customer satisfaction by $38.6 \%$ and the rest from other variables

\section{PENDAHULUAN}

Perkembangan perdagangan di perubahan zaman globalisasi mengalami persaingan yang sangat kompetitif antar pesaing yang akan berdampak pada keberlangsungan perusahaan. Perusahaan dituntut dalam mengembangkan inovasi untuk mendapatkan perhatian dari konsumen atas produk maupun jasa. Persaingan yang begitu ketat di dunia bisnis, pelaku usaha dituntut memiliki kepekaan akan semua perubahan-prtubahan dipersiangan guna memenuhi kebutuhan konsumen dan memprioritaskan orientasi kepuasan pelanggan sebagai tujuannya. Perusahaan akan mampu bersaing dan sukses jika bisa menciptakan dan mempertahankan pelanggan terhadap produk atau jasanya.

Konsumen dalam melakukan pembelian harapan yang diinginkannya yang menimbulkan kepuasan pembelian terhadap produk. Kepuasan pembelian konsumen bergantung akan manfaat dari produk yang dibelinya, sehingga harapan konsumen sesuai dengan harapan dan keinginan. Apabila produk jauh dibawah dari harapan pembeli atau konsumen, maka tidak ada rasa kepuasan pada produk dan apabila produk mampu memenuhi harapan akan timbul kepuasan pelanggan (Suharyadi, 2018). Kepuasan diperoleh konsumen akan produk yang dibelinya akan berimbas pada kegunaan produk. 


\section{JURNA \\ ANALISIS, PREDIKSI, DAN INFORMASI}

Produk yang bisa memenuhi keinginan konsumen, yang dapat mempengaruhi konsumen dalam pengambilan keputusan dalam melakukan pembelian selanjutnya. Lumentut dan Palandeng (2014) pengambilan keputusan sebagai alternatif pilihan konsumen dalam melakukan pembelian yang ddisediakan dari penjual ke konsumen. Seseorang pembeli dihadapkan dalam keadaan dimana terdapat macam pilihan untuk menentukan pilihan.

Kepuasan pelanggan ditrntukan setelah pembeli melakukan pembelian dan memakai atau menikmati produk atau jasa yang didapatkannya, jika dengan diharapkannya. Adanya kualitas produk kebutuhan dan keinginan konsumen akan terpenuhi. Jika kualitas produk memenuhi diatas standar ataupun standar, maka produk mendapatkan nilai berkualitas (Hanila \& Hidayat, 2019). Purnamasari (2015) proses pembelian konsumen dalam melakukkan mempertimbangkan kualitas produk. Konsumen memilih membeli produk berkualitas tinggi dibandingkan dengan produk yang berkualitas rendah. Harga yang terjangkau diikuti dengan penilaian kulaitas suatu produk yang baik oleh konsumen dalam pembelian yang selanjutnya. Kualitas produk yang baik akan dipertimbangkan dalam melakukan pembelian dengan tujuan untuk memenuhi kebutuhannya. Kualitas produk yang berkualitas membuat minat beli dalam keputusan pembelian. (Pasaribu \& Prayoga, 2019).

Citra merek dapat mempengaruhi kepuasan pelanggan dengan persepsi konsumen terhadap citra produk memengaruhi dalam persepsi konsumen serta penilaian konsumen. Apabila citra suatu produk memiliki nilai yang lebih dan mempunyai penilaian unggul dari produk lain membuat merek melekat dihati konsumen (Rafidah \& Lasika, 2019). Citra merek terbrntuk dari bebrapa persepsi konsumen pada suatu merek produk yang telah dibelinya, atas berbagai macam perbandingan bebrapa produk lainnya. Citra merek dalam strategi pengembangkan agar kuat dan melekat di konsumen merupakan cara membuat konsumen mengenalkan produk sebagai alternatif pilihan konsumen (Marsellina \& Budiono, 2019). 
Strategi dalam memikat konsumen baru untuk berkunjung dengan meingkatkan, mempertahankan konsumen, menghindari konsumen pindah dan keunggulan khusus untuk pembeli. Mengutamakan kualitas pelayanan berdampak pada kepuasan pelanggan dalam melakukan pemelian. Kualitas pelayanan uapaa yang dilakukann perusahaan untuk memnuhi kebutuhan konsumen sesuai yang diharapkannya (Robustin, 2018).

Kualitas pelayanan memiliki hubungan terhadap kepuasan pelanggan untuk keberlangsungan suatu usaha. Pengaruh yang diproyeksikan jangka panjang, memungkinkan akan memahami harapan konsumen. Perusahaan harus berupaya meningkatkan kepuasan pelanggannya sesuai dengan harapan dan keinginan konsumen (Alfiah \& Nitasari, 2020).

Factory outlet yang didirikan di berbagai Mall diprediksikan mempunyai peluang yang tinggi untuk mengembangkan suatu usaha bisnis. Factory outlet dengan memperluas relasi pemasaran dalam penjualannya, tujuannya untuk percepatan penjualan untuk mengembangkan usaha. Factory outlet harus berusaha membuat inovasi yang menjadi ikon dari merek produk dari perusahaan. 3 Second merupakan bisnis retail yang pemasarannya sangat luas, salah satunya yang berlokasi di Solo Grandmall, karena peneliti ingin mengetahui seberapa konsumen merasakan kepuasan setelah melakukan pembelian produk dari 3Second. Seiring banyaknya kompetitor baru 3Second mengalami berkurangnya citra mereknya berbagai kalangan yang disusul dengan munculnya kompetitor baru yang memproduksi produk yang lebih berkulitas dan harga yang terjangkau.

Observasi dan wawancara kepada konsumen kualitas produk 3Second produk yang dijual terlalu mahal dengan kualitas yang relatif kurang sepadan. Pelayanan karyawan yang kurang maksimal yang membuat konsumen mengeluhkan pelayanan yang kurang 
menyenangkan. Walaupun 3Second mempunyai reputasi terhadap merek dagangnya, akan tetapi konsumen tidak hanya mengedepankan merek yang terdapat pada produk tetapi juga memperhitungkan kualitas dan harga yang terjangkau.

\section{Kepuasan pelanggan}

Kepuasan pelanggan hasil dari penilaian produk/pelayanan memberikan kenikmatan pemenuhan iyang dirasa bisa memenuhi keinginananya. Kepuasan Pelanggan feeling pembeli perasaan yang memenuhi harapan. Kepuasan Pelanggan perilaku setelah pembelian sikap puas maupun tidak pada konsumen, kepuasan pelanggan fungsi harapan pembeli jasa yang dirasakan Terdapat bebrapa dari Indikator kepuasan pelanggan (Tjiptono, 2011: 229). Yaitu:
a. Kesesuaian harapan jasa
b. Persepsi kinerja jasa
c. Penilaian konsumen

\section{Kualitas produk}

Produk aspek penting mendapatkan persepsi baik konsumen, produk salah satu variabel dapat menentukan kegiatan dalam suatu usaha perusahaan. Adanya produkk dapat menciptakan tujuan yang dapat diharapkan (Kotler \& Keller, 2016: 389). Terdapat indikator kualitas produk (Tjiptono, 2014: 75).
a. Kinerja atau fungsi dasar produksi.
b. Fitur pelengkap dari produk.
c. Ketahanan produk.
d. Kesesuaian, standarisasi suatu produk.
e. Daya tahan produk waktu tertentu.
f. Pelayanan yang ditetapkan.
g. Daya tarik secara estetika.
h. Persepsi produk yang dihasilkan 


\section{Citra merek}

Merek penamaan yang dilakukan oleh penyedia jasa ataupun produsen penghasil barang yang meamakan produk atau layanan jasanya agar diketahui dan bisa mudah dan cepat dimengerti oleh konsumen. Penamaan merek bila sukses dipasar akan mengalami kenaikan nama di masyarakat akan akan mengalami kenalikan trand melakaukan kunjungan ataupun pembelian Merek merupakan terbaik akan dapat memberikan berupa jaminan kualitas. Pemberian nama dari merek produk tidak hanya suatu simbol tetapi atribut, manfaat dari suatu produk, nilai akan suatu produknya (Rangkuti, 2012:2). Indikator citra merek Kotler dan Keller (2013: 342) sebagai berikut:
a. Kesesuaian Ekonomi
b. Kesesuaian Simbolik
c. Kesesuaian Perasaan
d. Kesesuaian futuristic
e. Kesesuaian Kegunaan

\section{Pelayanan}

Kualitas pelayanan yang baik pada tingkat yang berkualitas dan memuaskan konsumen (Fandy, 2012: 95). Mutu pelayanan akan dapat diketahui dengan cara meminta pendapat terhadap apa yang sudah diterimanya. Salah satunya yaitu dengan penyebaran kuesioner kepada responden (Alfiah \& Nitasari, 2020). Indikator pelayanan (Kotler \& Keller, 2013: 176) yaitu:
a. Bukti fisik
b. Reliability
c. Tanggapan
d. Jaminan 


\section{JURNA A

\section{e. Empathy}

\section{METODE PENELITIAN}

Jenis penelitian deskriptif kuantitatif. Tempat penelitian di Factory outlet 3Second Solo GrandMall, Surakarta, Jawa Tengah. Populasi dalam penelitian menggunakan seluruh konnsumen 3Second Solo GrandMall dan sampel dalam penelitian yaitu menggunakan sampel accidental sampling dengan mengambil 100 responden dengan metode analisi regresi berganda. Penulis memilih lokasi tersebut dengan alasan kualitas produk 3Second produk yang dijual terlalu mahal dengan kualitas yang relatif kurang sepadan. Pelayanan karyawan yang kurang maksimal yang membuat konsumen mengeluhkan pelayanan yang kurang menyenangkan. Walaupun 3Second mempunyai reputasi terhadap merek dagangnya, akan tetapi konsumen tidak hanya mengedepankan merek yang terdapat pada produk tetapi juga memperhitungkan kualitas dan harga yang terjangkau.

\section{HASIL DAN PEMBAHASAN}

ANALISIS DATA

Uji Hasil Normalitas

Tabel 6

\begin{tabular}{lcc}
\hline \multicolumn{1}{c}{ Variabel } & $\begin{array}{c}\text { Kolmogorov- } \\
\text { Smirrov }\end{array}$ & $p$-value \\
\hline $\begin{array}{l}\text { Unstandardized } \\
\text { Residual }\end{array}$ & 0.061 & 0.200 \\
\hline
\end{tabular}

Hasil Tabel 3 nilai signifikansi dengan nominal 0.061 dan Nilai signifikansi dengan nominal hasil 0,200. Hasil Kolmogorov-Smirnov dengan nominal signifikansi lebih besar dari 0,05. Maka semua pertanyaan yang diolah berdistribusi normal. 


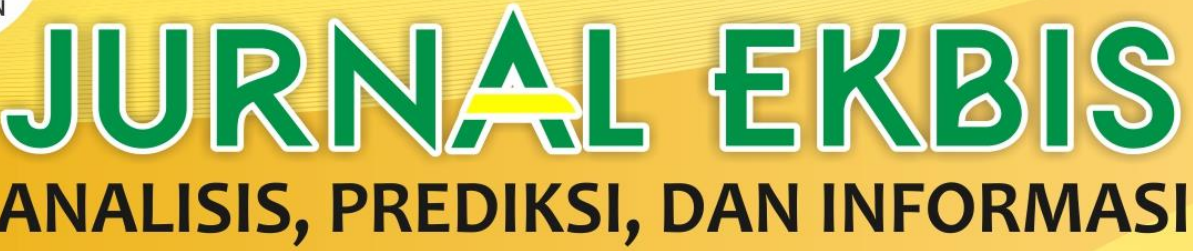

\section{Uji multikolinearitas}

Tabel 7

\begin{tabular}{ccc}
\hline Variabel & Tolerance & VIF \\
\hline $\mathrm{X}_{1}$ & 0,915 & 1.093 \\
$\mathrm{X}_{2}$ & 0,897 & 1.115 \\
$\mathrm{X}_{3}$ & 0,963 & 1.039
\end{tabular}

Hasil dari Tabel 7 Nilai VIF $<10$ dan nilai hasil dari tolerance mendekati 1 atau diatas 0,1. Berarti tidak terdapat masalah multikolinearitas.

\section{Uji Heterosakedastisitas}

Tabel 8

\begin{tabular}{cc}
\hline Variabel & P-value \\
\hline $\mathrm{X}_{1}$ & 0,060 \\
$\mathrm{X}_{2}$ & 0,083 \\
$\mathrm{X}_{3}$ & 0,517 \\
\hline
\end{tabular}

Hasil dari Tabel 8 Nilai p-value > 0,05, variabel bebas dari masalah heteroskedastisitas.

\section{Hasil Uji Hipotesis}

Tabel 9

\begin{tabular}{lc}
\hline \multicolumn{1}{c}{ Variabel } & Koefisien Regresi (B) \\
\hline (Constant) & 3,038 \\
$\mathrm{X}_{1}$ & 0,183 \\
$\mathrm{X}_{2}$ & 0,311 \\
\hline
\end{tabular}




\section{JURNA A

1. Nilai konstanta 3,038, semua variabel bebas dianggap konstan, maka tingkat kepuasan pelanggan akan meningkat sebesar 3,038.

2. $b_{1}=0,183$ kualitas produk $\left(X_{1}\right)$ bernilai nilai positif, apabila citra merek $\left(X_{2}\right)$ dan pelayanan $\left(\mathrm{X}_{3}\right)$ diangganp konstan, maka ada peningkatkan kualitas produk $\left(\mathrm{X}_{1}\right)$ mengakibatkan kepuasan pelanggan mengalami peningkatan yaitu 0,183.

3. $b_{2}=0,311$ citra merek $\left(X_{2}\right)$ bernilai positif, apabila kualitas produk $\left(X_{1}\right)$ dan pelayanan $\left(\mathrm{X}_{3}\right)$ konstan, maka terjadi peningkatkan citra merek $\left(\mathrm{X}_{2}\right)$ dapat meningkatkan kepuasan pelangan yaitu 0,311 .

4. $b_{3}=0,290$ pelayanan $\left(X_{3}\right)$ bernilai positif, apabila kualitas produk $\left(X_{1}\right)$ dan merek $\left(\mathrm{X}_{2}\right)$ dianggap konstan, maka terjadi peningkatkan pelayanan $\left(\mathrm{X}_{3}\right)$ ) dapat meningkatkan kepuasan pelangan yaitu 0,290.

\section{Uji R2/Determinasi}

Tabel 10

Adjusted R Square

0,386

Nilai Adjusted $R$ square sebesar 0,386, berarti variasi perubahan variabel kepuasan pelanggan dapat dijelskan oleh variabel kualitas produk $\left(\mathrm{X}_{1}\right)$, citra merek $\left(\mathrm{X}_{2}\right)$, pelayanan $\left(\mathrm{X}_{3}\right)$ sebesar $38,6 \%$. lainnya $68,3 \%$ dijelaskan oleh variabel lain seperti lokasi, fasilitas, store atmosphere dan lainnya. 


\section{Uji F}

Tabel 11

\begin{tabular}{lccc}
\hline Variabel & $\mathrm{F}_{\text {hitung }}$ & $\mathrm{F}_{\text {tabel }}$ & Sig Probabilitas) \\
\hline $\mathrm{X}_{1}$ & & & \\
$\mathrm{X}_{2}$ & 21,725 & 2,70 & 0,000 \\
$\mathrm{X}_{3}$ & & & \\
\hline
\end{tabular}

Nilai $F_{\text {hitung }}>F_{\text {tabel }}$ dengan nominal nilai $20.641>2,70$ ), secara bersama-sama yaitu dari variabel bebas telah mempengaruhi kepuasan pelanggan 3Second.

Uji t

Tabel 12

\begin{tabular}{lccc}
\hline Variabel & $\mathrm{t}_{\text {hitung }}$ & $\mathrm{t}_{\text {tabel }}$ & Sig. \\
\hline $\mathrm{X}_{1}$ & 2,385 & 1,985 & 0,019 \\
$\mathrm{X}_{2}$ & 4,569 & 1,985 & 0,000 \\
$\mathrm{X}_{3}$ & 4,251 & 1,985 & 0,000 \\
\hline
\end{tabular}

$t_{\text {hitung }}$ lebih besar $t_{\text {tabel }}(1,987)$ dengan nominal nilai nominal signifikan lebih kecil dari angka $0,05(\alpha)$ variabel dari semuanya signifikan dan secara persial berpengaruh positif terhadap kepuasan pelanggan 3Second.

Kualitas produk, citra merek, pelayanan berpengaruh signifikan pada kepuasan pelanggan 3Second.

\section{Pembahasan}




\section{JURNA A \\ ANALISIS, PREDIKSI, DAN INFORMASI}

Berdasarkan observasi dan wawancara kepada konsumen kualitas produk 3Second produk dengan harga yang kompetitif dengan merek lainnya. Pelayanan karyawan yang maksimal membuat konsumen merasa menyenangkan dan merasa diprioritaskan. 3Second mempunyai reputasi terhadap merek dagangnya, akan tetapi konsumen tidak hanya mengedepankan merek yang terdapat pada produk tetapi juga memperhitungkan kualitas dan harga yang terjangkau. 3Second memiliki produk yang ditawarkan original dan mempunyai icon.

\section{Kualitas produk berpengaruh positif signifikan pada kepuasan pelanggan.}

Kualitas produk 3Second yang ditawarkan sesuai yang diinginkan konsumen dengan memiliki bahan yang berkualitas, desain yang selalu mengikuti perkembangan trend. 3Second dengan produk yang dihasilkan selalu membuat dengan trend saat itu juga, dengan kombinasi warrna produk yang ditawarkan mempunyai bervariasi menarik. Produk mempunyai gambar sablon yang tidak mudah retak atua mengelupas, hiasan baju atau pernak-pernik mengkombinasi setiap produk 3Second untuk menambah esensi dari suatu produk tersebut dengan style produknya yang berkualitas. Hasil penelitian ini mendukung penelitian sebelumnya yang dilakukan oleh (Hanila \& Hidayat, 2019), dan (Ayuningtias \& Djoko W, 2017).

\section{Citra merek berpengaruh positif signifikan pasa kepuasan pelanggan.}

Persepsi konsumen terhadap citra produk 3Second sangat melekat oleh konsmen. Penilaian konsumen terhadap 3Second sanat baik maka merek memiliki nilai positif yang akan membuat merek tersebut melekat di hati konsumen. Hasil penelitian ini mendukung penelitian sebelumnya yang dilakukan oleh (Marsellina \& Budiono, 2019) dan (Susanto, 2019).

\section{Pelayanan berpengaruh positif signifikan pada kepuasan pelanggan.}

Karyawan di 3Second handal dari awal sampai akhir melayani konsumen dengan baik. Daya tangggap karyawan baik dengan dibuktikan dengan melayani dengan cepat 
disetiap kegiatannya. Saat konsumen mengalami kesulitan, pegawai menyelesaikan dengan cepat dan memuaskan. Konsumen menyatakan kesopanan karyawan sangat diapresiasi. Dalam menikmati di lokasi merasa aman baik dari diri maupun kendaraannya. Empati yang dirasakan oleh konsumen ketika berada di 3Second. Wujud empati yang dirasakan oleh konsumen adalah ketika konsumen dapat dengan mudah dapat menghubungi karyawan setiap saat bila dibutuhkan oleh konsumen 3Second, hal tersebut menunjukkan kepedulian karyawan pada konsumen. Hasil tersebut didukung (Robustin, 2018), (Alfiah \& Nitasari, 2020) playanan berpengaruh berpengaruh pada loyalitas pelanggan.

\section{KESIMPULAN DAN SARAN}

\section{Kesimpulan}

Hasil penelitian kualitas produk, citra merek, pelayanan berpengaruh signifikan secara bersama-sama maupun secara parsial terhadap kepuasan pelanggan. Kontribusi dari ketiga variabel bebas menjukkan dengan nilai sebesar 38,6\% dan 61,4 dapat disimpulkan dipengaruhi variabel lain.

\section{DAFTAR PUSTAKA}

Alfiah, \& Nitasari, A. (2020). Pengaruh Antara Harga , Kualitas Pelayanan terhadap Kepuasan Konsumen Pada Toko Sport Station Kota Batu. Jurnal Aplikasi Manajemen dan Inovasi Bisnis, 106-119.

Ayuningtias, T., \& Djoko W, H. (2017). Pengaruh Kualitas Produk, Citra Merek Dan Iklan Terhadap Keputusan Pembelian Kartu XL Prabayar Di Kota Semarang (Studi Kasus Pada Pengguna Kartu Xl Prabayar Di Kota Semarang). Diponegoro Journal Of Social And Political, 1-6. 


\section{JURNAA L \\ ANALISIS, PREDIKSI, DAN INFORMASI}

DJ, Y. R., \& Titin, T. (2020, October). THE EFFECT OF E-RECRUITMENT AND SPIRIT AT WORK ON EMPLOYEE ACHIEVEMENT AT PT X IN SURABAYA. In 1st International Conference of Business and Social Sciences.

DJ, Y. R. (2019). PENGARUH HARGA KAMAR DAN FASILITAS HOTEL TERHADAP KEPUASAN KONSUMEN DI SHANGRILA HOTEL SURABAYA. JPIM (Jurnal Penelitian Ilmu Manajemen), 4(1), 889-896.

DJ, Y. R. (2019). PENGARUH KUALITAS PRODUK DAN PROMOSI TERHADAP KEPUTUSAN PEMBELIAN PRODUK SMARTPHONE OPPO. Media Mahardhika, 17(3), 463-466.

Efendi, Y., Mauladi, K. F., Rahmi, C. A., \& Afifah, D. N. (2020). Pelatihan Dan Bantuan Dalam Program Pemberdayaan Ekonomi Pada Masa Pandemi Di Desa Tiwet Kecamatan Kalitengah Kabupaten Lamongan. Jurnal Karya Abdi Masyarakat, 4(3), 711-714.

Fandy, Tjiptono. (2012). Service Management: Mewujudkan Pelayanan Prima. Service Management: Mewujudkan Pelayanan Prima.

Frendy. Tjiptono (2011). Metode Penelitian untuk Bisnis. Jakarta: Salemba Empat.

Ghofur, A., Agustina, N., \& Elvierayani, R. R. (2019). Evaluation Of Production Cost Control Using Flexible Budget And Direct-Cost Variance In Restaurant Lamongan Sport Center: Evaluation Of Production Cost Control Using Flexible Budget And Direct-Cost Variance In Restaurant Lamongan Sport Center. Jurnal Mantik, 3(3), 162-166.

Hanila, S., \& Hidayat , R. (2019). Hubungan Harga Dan Kualitas Produk Dengan Kepuasan Pelanggan Pada Toko Perlengkapan Baju Sekolah Elis Kota Bengkulu. Ekombis Review, 50-57.

Kotler, P., \& Keller, K. L. (2013). Marketing Managemet. New Jersey: Pearson Education.

Lumentut, F., \& Palandeng, I. (2014). Fasilitas, Servicescape, Dan Kualitas Pelayanan, Pengaruhnya Terhadap Kepuasan Konsumen Mcdonald's Manado. Jurnal EMBA, 02(03), 126-136, ISSN 2303-1174.

Marsellina, \& Budiono, H. (2019). Pengaruh Kepercayaan Merek Dan Citra Merek Terhadap Kepuasan Pelanggan Uniqlo Di Jakarta. Jurnal Manajerial dan Kewirausahaan, 788-794.

Volume 22 No 1 (2021) 
Pasaribu, V. D., \& Prayoga, M. S. (2019). Pengaruh Kualitas Produk Baju Batik Hem Terhadap Kepuasan Pelanggan Pada Home Industri Batik Sahara Indah. Jurnal Pemasaran Kompetitif, 77-83.

Rafidah, \& Lasika, M. D. (2019). Pengaruh Kepercayaan Merek, Kualitas Pelayanan Islami Dan Promosi Terhadap Kepuasan Pelanggan Outlet Rabbani Di Kota Jambi. Iltizam Journal Of Shariah Economic Research, 58-78.

Robustin , T. P. (2018). Pengaruh Atribut Produk Dan Kualitas Pelayanan Dalam Menciptakan Kepuasan Pelanggan Produk Sophie Paris Di Kecamatan Kaliwates Jember. Global, 57-64.

Suharyadi, D. (2018). Analisis Pengaruh Kualitas Pelayanan Terhadap Kepuasan Pelanggan Pada Toko Yoehan Wanaherang Bogor. Jurnal ilmu pengetahuan dan komputer, 289-296.

Susanto, A. (2019). Pengaruh Merek, Desain Produk Dan Lokasi Terhadap Minat Beli Konsumen Pada Persebaya Store Gresik. JRE: Jurnal Riset Entrepreneurship, 6267. 